\title{
PEMANFAATAN SUMBER BELAJAR DALAM BIDANG BIMBINGAN DAN KONSELING
}

\author{
Purbatua Manurung
}

Universitas Islam Negeri Sumatera Utara Medan

Jl. Williem Iskandar Pasar V Medan Estate, Kota Medan, Sumatera Utara

e-mail: purbatuamanurung2017@gmail.com

\begin{abstract}
Penelitian ini bertujuan untuk menganalisis pemanfaatan sumber belajar dalam bidang bimbingan konseling. Penelitian ini menggunakan metode penelitian kualitatif berbasis studi kepustakaan (library Research). Pengumpulan data menggunakan teknik dokumentasi yang berasal dari sumber-sumber kepustakaan. Analisis data menggunakan teknik analisis isi dimana setiap sumber atau literatur yang dipakai disesuaikan dan dilihat kesesuaian konteksnya dengan literatur lainnya baik dari buku, jurnal atau penelitian lainnya. saat ini kualitas pembelajaran dan pendidikan masyarakat sangat dipengaruhi dengan kondisi sumber belajar yang ada, dan hal ini tidak bisa dipungkiri sebab jika kondisi dan ketersediaan sumber belajar memadai, maka proses belajar bisa berjalan dengan baik. Secara tidak langsung hal ini menunjukkan betapa pentingnya pemanfaatan sumber belajar dalam sebuah proses pembelajaran. Dalam ranah bimbingan dan konseling sumber belajar erat kaitanya dan kerap digunakan dalam beragam pelaksanaan layanan bimbingan dan konseling, baik di dunia pendidikan secara formal maupun nonformal, dalam hal ini sumber belajar yang dikaitkan dapat berupa beragama hal atau instrumen yang digunakan dalam kesuksesan pelaksanaan layanan bimbingan dan konseling.
\end{abstract}

Kata Kunci: Sumber Belajar, Bimbingan dan Konseling, Pembelajaran

\begin{abstract}
This study aims to analyze the use of learning resources in the field of counseling guidance. This study uses a qualitative research method based on library research (library research). Collecting data using documentation techniques derived from library sources. Data analysis uses content analysis techniques where each source or literature used is adjusted and the context's suitability is seen with other literature from books, journals or other research. At present the quality of learning and community education is strongly influenced by the conditions of existing learning resources, and this cannot be denied because if the conditions and availability of learning resources are adequate, the learning process can run well. This indirectly shows how important it is to use learning resources in a learning process. In the realm of guidance and counseling, learning resources are closely related and are often used in various implementation of guidance and counseling services, both in the formal and non-formal world of education, in this case the associated learning resources can be in the form of religion or instruments used in the successful implementation of guidance and counseling services.
\end{abstract}

Keywords: Learning Resources, Counseling and Guidance, Learning 


\section{PENDAHULUAN}

Sumber belajar adalah segala sesuatu yang berwujud benda dan orang yang dapat menunjang belajar sehingga mencakup semua sumber yang mungkin dapat dimanfaatkan oleh tenaga pengajar agar terjadi perilaku belajar. Kemudian menurut Januszewski dan Molenda, (2008) sumber belajar adalah semua sumber termasuk (1) pesan, (2) orang, (3) bahan, (4) alat, (5) teknik, dan (6) latar yang dapat dipergunakan peserta didik baik secara sendiri sendiri maupun dalam bentuk gabungan untuk menfasilitasi kegiatan belajar dan meningkatkan kinerja belajar. (Abdullah, 2012).

Sejalan dengan pendapat itu, Seels dan Richey (1994) menjelaskan bahwa sumber belajar adalah segala sumber pendukung untuk kegiatan belajar, termasuk sistem pendukung dan materi serta lingkungan pembelajaran. Sumber belajar bukan hanya alat dan materi yang dipergunakan dalam pembelajaran, tetapi juga meliputi orang, anggaran, dan fasilitas. Sumber belajar bisa termasuk apa saja yang tersedia untuk membantu seseorang belajar. (Seels \& Richey, 2012). Bahwa sumber belajar yang beraneka ragam di sekitar kehidupan, baik yang didesain maupun yang dimanfaatkan pada umumnya belum dimanfaatkan secara maksimal, penggunaannya masih terbatas pada buku teks. Ternyata dari sekian banyak sumber belajar yang ada, buku teks saja yang merupakan sumber belajar yang dimanfaatkan. (Warsita, 2018).

Sebagaimana bidang pendidikan, bimbingan dan konseling juga memerlukan sumber belajar ketika melakukan aktivitas bimbingan dan konseling baik secara formal maupun nonformal. Secara umum bimbingan dan konseling merupakan hubungan bantuan antara dua pihak yaitu antara siswa atau klien dengan konseli atau guru BK. Dalam hal ini klien merupakan individu yang sedang berkembang mempunyai masalah dan mempunyai dorongan untuk menyelesaikan masalah. Dalam hal ini individu membutuhkan upaya pemahaman diri dan selanjutnya mendukung dalam pengambilan keputusan. (Basri, 2010).

Maka dalam hal ini, kemampuan konselor dalam menerapkan berbagai pendekatan konseling harus sesuai dengan masalah dan kebutuhan klien sehingga pendekatan yang diterapkan dapat efektif mengatasi berbagai gangguan ataupun masalah yang dialami oleh konseli, dalam hal ini khususnya penggunaan sumber belajar dapat dimanfaatkan oleh konselor dalam upaya penyelesaian kesulitan yang dialami oleh klien. (Setiawan, 2018).

\section{METODE PENELITIAN}

Penelitian ini menggunakan metode penelitian studi pustaka. teknik pengumpulan data dengan mengadakan studi telaah terhadap buku-buku, literatur-literatur, catatan-catatan, dan laporan-laporan yang ada hubungannya dengan masalah yang dipecahkan. Sumber data utama yang digunakan dalam penelitian ini difokuskan pada beragam sumber baik dari buku, jurnal maupun penelitian terbaru yang relevan dengan konteks penelitian ini yaitu pemanfaatan sumber belajar dalam bidang bimbingan dan konseling. Pada analisis data 
penelitian ini menggunakan analisis isi, dimana setiap sumber atau literatur yang dipakai disesuaikan dan dilihat kesesuaian konteksnya dengan literatur lainnya baik dari buku, jurnal atau penelitian lainnya. Pada penelitian ini menggunakan teknik pengumpulan data yang digunakan ialah dengan dengan metode dokumentasi, yaitu mencari data mengenai hal-hal atau variabel yang berupa catatan, buku, makalah atau artikel, jurnal, dan sebagainya.

\section{HASIL DAN PEMBAHASAN}

\section{Sumber Belajar Dalam Pembelajaran}

Optimalisasi hasil belajar ini dapat dilihat tidak hanya dari hasil belajar saja, namun juga dilihat dariproses pembelajaran yang berupa interaksi siswa dengan berbagai sumber belajaryang dapat memberikan rangsangan untuk belajar dan mempercepat pemahamandan penguasaan bidang ilmu yang dipelajari. Pada sistem pembelajaran konvensional, kebanyakan akan ditemui pemanfaatan sumber belajar yang kaku dan masih terbatas pada satu sumber saja, padahal setidaknya ada 6 jenis sumber belajar yang kini telah disepakati dan digunakan dalam literatur ilmiah. Saat ini, Pemanfaatan sumber belajar dalam pembelajaran termasuk bidang bimbingan dan konseling hanya berfokus dan terpusat pada informasi yang disampaikan oleh guru sedangkan sumber belajar lainnya tidak mendapat perhatian yang diharapkan, harusnya sumber belajar lainnya dapat digunakan dan dimanfaatkan dalam mendukung proses pembelajaran. (Yuhana \& Aminy, 2019).
Hal ini pula yang menyebabkan masih kurang berkembangnya aktivitas pembelajaran yang dilakukan, secara spesifik ketika pembelajaran tidak berjalan dengan baik maka pembelajaran tidak akan mencapai tujuan secara ideal, maka untuk memperbaiki ini semua diperlukan dukungan serta pemanfaatan dari seluruh sumber belajar yang tersedia. Dalam kaitan bimbingan dan konseling merupakan kesatuan utuh sistem pembelajaran maka ketika ingin mencapai tujuan akhir bimbingan dan konseling yaitu memandirikan siswa/klien, harusnya dapat memanfaatkan seluruh sumber belajar yang tersedia sehingga tujuan ideal bimbingan dan konseling dapat dicapai secara utuh. (Sodik, 2016).

Secara umum sumber belajar terdiri atas enam poin penting, dalam kaitan sumber belajar dengan bidang bimbingan dan konseling diuraikan sebagai berikut. Sebagaimana AECT (Association of Education and Communication Technology), yaitu pesan, orang, bahan, alat, teknik dan latar atau lingkungan, yaitu:

1. Pesan, adalah kurikulum atau mata pelajaran yang terdapat pada masingmasing sekolah atau jenjang pendidikan dan yang perlu dipelajari oleh murid. Dalam ruang lingkung bimbingan dan konseling, hal ini dapat berupa program layanan bimbingan dan konseling mulai program tahunan, semeseteran, bulanan, mingguan hingga harian dan satuan layanan (L1-L9) yang merupakan acuan ketika hendak melakukan pelayanan bimbingan dan konseling kepada siswa. Hal-hal ini nantinya yang dapat 
digunakan oleh pelaksana program bimbingan dan konseling ketika melakukan pemberian layanan sehingga proses dan tujuan pemberian layanan dapat berjalan serta tercapai dengan baik.

2. Orang, antara lain guru, tutor, pembimbing dan sebagainya adalah yang menyampaikan pesan pembelajaran kepada peserta didik. Dalam ruang lingkup bimbingan dan konseling dapat diartikan dan biasa disebut sebagai konselor, guru bk ataupun konselor sekolah.

3. Bahan, adalah program yang memuat atau berisi pesan pembelajaran seperti buku, program video atau audio, VCD dan lain-lain. Dalam ruang lingkung bimbingan dan konseling, bahan dapat berupa alat peraga, kartu game, media layanan berupa digital yang akan digunakan atau ditampilkan ketika melaksanakan pemberian layanan kepada klien atau siswa.

4. Alat, adalah sarana untuk menayangkan bahan atau program seperti proyektor film, video recorder, OHP, dan sebagainya. Alat disini berfungsi dan dimanfaatkan untuk menampilkan media rekaman digital berbentuk audio maupun video yang dapat mendukung tercapainya tujuan pelaksaan bimbingan dan konseling.

5. Teknik, adalah prosedur yang digunakan untuk menyampaikan pesan pembelajaran seperti diskusi, karyawisata, mereka yang menjalankan fungsi pengembangan dan pengelolaan sumber belajar. Dalam bimbingan dan konseling dikenal beragam teknik yang digunakan ketika hendak memulai konseling baik secara individu maupun kelompok. Mulai dari teknik attending hingga empati, hal ini digunakan agar terjadi proses konseling yang nyaman, terarah, terstruktur.

6. Latar (settings), yaitu lingkungan di mana belajar dan pembelajaran berlangsung misalnya di kelas, di taman, penerangan dan ventilasi ruangan, dan sebagainya. Agar dapat berfungsi secara optimal dalam kegiatan belajar dan pembelajaran, sumber belajar tersebut perlu dikembangkan dan dikelola dengan sebaik-baiknya. Proses pemberian layanan dan konseling dalam bimbingan konseling memiliki standar tertentu dan aturan, misalnya ketika melakukan proses konseling maka hendaknya diruangan yang nyaman dan aman agar percakapan selama konseling yang bersifat rahasia dapat dijaga kerahasiaanya, selain itu ukuran ruangan, penerangan, serta tat letak ruangan juga akan mempengaruhi dalam pelaksanaan proses pemberian layanan dalam bimbingan dan konseling. (Tafonao, 2018).

Media pembelajaran dalam layanan bmbingan konseeling juga sebagai sumber belajar. Sekarang kita menelaah media sebagai sumber belajar dalam layanan bimbingan konseling. Sumber belajar adalah segala sesuatu yang dapat dipergunakan sebagai tempat bahan pembelajaran untuk belajar peserta didik tersebut berasal. Sumber belajar dapat dikelompokkan menjadi lima kategori, yaitu manusia, buku perpustakaan, media massa, alam 
lingkungan, dan media pendidikan. Media pendidikan, sebagai salah satu sumber belajar, ikut membantu guru/konselor dalam memudahkan tercapainya pelaksanaan laanna bimbingan dan konseling. Itulah mengapa guru/konselor harus bisa menguasai dan memanfaatkan sumber belajar dalam bimbingan konseling. (Basri, 2010).

Sering guru menentukan buku teks sebagai satu-satunya sumber materi pelajaran. Bahkan, pembelajaran yang berorientasi kepada kurikulum subjek akademis, buku teks yang telah disusun oleh para pengembang kurikulum merupakan sumber utama. Dengan demikian, perubahan dan atau penyempurnaan kurikulum, pada dasarnya adalah penyempurnaan dan perubahan buku ajar. Akibat, ketika terjadi perubahan kurikulum, maka selalu diikuti oleh perubahan buku pelajaran. (Prasetiawan, 2017).

Dalam hal layanan bimbingan dan konseling buku pelajaran bukan merupakan satu-satunya sumber bahan pelajaran, alasannya, karena:

1. Ilmu pengetahuan berkembang sangat cepat, sehingga kalau guru fan siswa hanya mengandalkan buku teks sebagai sumber pembeljaran, bisa terjadi materi yang dipelajarinya itu akan cepat usang. Dengan demikian, guru dituntut untuk menggunakan sumber lain yang dapat menyajikan informasi terbaru, misalnya menggunakan jurnal yang menyajikan berbagai pengetahuan mutakhir, majalah, koran dan sumber informasi elektronik, misalnya dengan menggunakan dan mamanfaatkan Internet dan lain sebagainya.

2. Kemajuan teknologi informasi, memungkinkan materi pelajaran tidak hanya disimpan dalam buku teks saja, akan tetapi bisa disimpan dalam berbagai bentuk teknologi yang lebih efektif dan efisien, misalnya dalam bentuk $\mathrm{CD}$, kaset, dan lain sebagainya. Dalam bentuk-bentuk semacam ini diyakini materi pelajaran akan lebih menarik untuk dipelajari sebab dengan berbagai teknik animasi, maka materi pelajaran akan lebih jelas dalam konkret. Sesuatu yang tidak mungkin disajikan dalam buku cetak karena keterbatasannya, maka dalam bentuk media elektronik akan dapat disajikan.

3. Tuntutan kurikulum seperti pada Kurikulum Tingkat Satuan Pendidikan (KTSP), menuntut siswa agar tidak hanya sekedar menguasai informasi teoretis, akan tetapi bagaimana informasi tersebut dapat dikembangkan sesuai dengan kebutuhan daerah dan lingkungan di mana siswa tinggal. Dengan demikian, kehidupan masyarakat nyata mestinya dijadikan sebagai salah satu bahan pelajaran. (El Fiah \& Purbaya, 2016).

Ketiga alasan tersebut, mestinya membuka wawasan baru bagi guru dalam bidang bimbingan dan konsseling bahwa ternyata banyak sumber yang dapat dimanfaatkan untuk membelajarkan siswa, selain dari buku teks yang dicetak secara masal. Guru yang hanya mengandalkan buku sebagai sumber materi pelajaran cenderung pengelolaan pembelajaran hanya menyajikan materi pelajaran yang belum tentu berguna 
untuk kehidupan siswa. Ataupun, seandainya materi pelajaran itu dianggap penting, maka siswa akan sulit menangkap pentingnya materi tersebut, selain hanya untuk dihafal. Itulah sebabnya selain buku teks, guru seharusnya memanfaatkan berbagai sumber belajar yang lain dalam hal laanan bimbingan dan konseling.

\section{Pemanfaatan Sumber Belajar dalam Bidang Bimbingan dan Konseling}

Sumber dapat dimanfaatkan untuk proses pembelajaran dalam hal bimbingan konseling dapat dikategorikan sebagai berikut:

1) Tempat atau lingkungan

Lingkungan merupakan sumber pelajaran yang sangat kaya sesuai dengan tuntutan kurikulum. Ada dua bentuk lingkungan belajar, yakni pertama lingkungan atau tempat yang sengaja didesain untuk belajar siswa seperti laboratorium, perpustakaan, ruang internet dan lain sebagainya. Lingkungan semacam ini dikenal dengan lingkungan by disign. Mengapa dikatakan by disign? Karena tempat semacam ini dirancang untuk proses pembelajaran. Kedua, lingkungan yang tidak didesain untuk proses pembelajaran akan tetapi keberadaannya dapat dimanfaatkan, misalnya halaman sekolah, taman sekolah, kantin, kamar mandi, dan lain sebagainya. Lingkungan yang demikian dikenal dengan lingkungan yang bersifat by utilism. Kedua bentuk lingkungan ini dapat dimanfaatkan oleh setiap guru karena memang selain memiliki informasi yang sangat kaya untuk membepalajari materi pembelajaran, juga dapat secara langsung dijadikan tempat belajar setiap siswa.

2) Orang atau nara sumber

Pengetahuan itu tidak statis, akan tetapi bersifat dinamis, yang terus berkembang sangat cepat. Oleh karena perkembangan yang secpat itu kadang-kadang apa yang disajikan dalam buku teks tidak sesuai lagi dengan perkembangan ilmu pengetahuan mutakhir. Misalnya, peraturan dan undang-undang baru mengenai sesuatu, penemuan-penemuan baru dalam berbagai ilmu pengetahuan mutakhir, seperti munculnya berbagai jenis penyakit misalnya flu burung, sapi gila, dan lain sebagainya serta berbagai jenis rekayasa genetik; munculnya berbagai fenomena alam serta pengaruhnya terhadap gejala-gejala sosial dan lain sebagainya, yang kesemuaannya itu tidak mungkin dipahami sepenuhnya oleh guru, maka untuk mempelajari konsepkonsep baru semacam itu, guru dapat menggunakan orang-orang yang lebih menguasai persoalan misalnya dengan mengundang dokter, Polisi dan lain sebagainya sebagai sumber bahan pelajaran dan bmbingan konseling.

3) Objek

Objek atau benda yang sebenarnya merupakan sumber informasi yang akan membawa siswa pada pemahaman yang lebih sempurna tentang sesuatu. Mempelajari bahan pelajaran dari benda yang sebenarnya bukan hanya dapat menghindari kesalahan persepsi tentang isi pelajaran, akan tetapi juga dapat membuat pelajaran lebih akurat di 
samping motivasi belajar siswa akan lebih baik.

4) Bahan cetak dan noncetak

Bahan cetak (printed material) adalah berbagai informasi sebagai materi pelajaran yang disimpan dalam berbagai bentuk tercetak, seperti buku, majalah, koran dan lain sebagainya. Sedangkan bahan belajar non cetak aadalah informasi sebagai materi pelajaran, yang disimpan dalam brbagai bntuk alat komunikasi elektronik yang biasanya berfungsi sebagai media pembelajaran misalnya dalam bentuk kaset, video, komputer, $\mathrm{CD}$, dan lain sebagainya. Terdapat tiga jenis bahan cetak dan non cetak yang dapat dijadikan sumber pelajaran. Pertama, bahanbahan yang dapat dijadikan sumber belajar utama untuk setiap individu. Pada bentuk ini bahan-bahan pelajaran disusun sedemikian rupa sehingga siswa dapat belajar secara individual, misalnya bahan cetakan seperti model atau pelajaran berprograma. Kedua, cetak yang disusun sebagai bahan penunjang, dan dirancang bukan sebagai bahan pelajaran individual. Artinya, belajar melalui bahan cetakan ini masih memerlukan guru atau instruktur secara langsung. Yang termasuk bahan jenis ini adalah buku-buku paket, diktat, hand-out dan lain sebagainya. Ketiga, bahan yang tidak dirancang khusus untuk pembelajaran, tetapi dapat dimanfaatkan untuk menambah pengetahuan dan wawasan dalam laanna bimbingan konseling dalam mempelajari sesuatu. Bahan yang demikian biasanya berisi tentang gagasan dan ide-ide pengarang secara bbas, atau berisi tentang hasil-hasil penelitian mutakhir dalam suatu bidang kajian tertentu. Yang termasuk ke dalam jenis ini adalah berbagai buku populer atau jurnal ilmiah. (Arifin, 2013).

Pendekatan yang berorientasi pada siswa adalah pendekatan dalam belajar yang ditekankan pada ciri-ciri dan kebutuhan siswa secara individual. Sedang lembaga pendidikan dan para pengajar berfungsi dan berperan sebagai penunjang saja. Sistem pendekatan yang berorientasi pada siswa ini di desainse demikian rupa. Sehingga siswa dapat belajar dengan sistem yang luwes yang diarahkan agar siswa dapat membenntuk gaya belajarnya masingmasing. Dalam hal ini guru dan lembaga berperan sebagai penunjang, fasilitator dan semangat pada siswa yang sedang belajar.

1. Media hasil teknologi audio-visual

Teknologi audi-visual cara menyampaikan materi dengan menggunakan mesin-mesin mekanis dan elektronis untuk menyajikan pesan-pesan audio-visual, penyajian pengajaran secara audio-visual jelas bercirikan pemakaian perangkat keras selama proses pembelajaran, seperti , mesin proyektor film, tape rekorder, proyektor visual yang lebar. (Basri, 2018).

2. Media hasil teknologi yang berdasarkan komputer

Teknologi berbasis komputer merupakan cara menghasilkan atau menyampaikanmateri dengan menggunakan sumber-sumber yang berbasis microprosesor. Berbagai aplikasi teknologi berbasis komputer dalam pembelajaran umumnya dikenalsebagai computer assisted instruction. 
Aplikasi tersebut apabila dilihat dari cara penyajiandan tujuan yang ingin dicapai melipiti tutorial,penyajian materi secara bertahap, drills end practice latihan untuk membantu siswa menguasai materi yang telah dipelajari sebelumnya, permainan dan simulasi (latihan untuk mengaplikasikan pengetahuan dan keterampilan yang baru dipelajari dari, dan basis data (sumber yang dapat membantu siswa menambahh informasi dan penegtahuan sesuai dengan keinginan masing-masing) Karakteristik media hasil teknologi yang berdasarkan komputer: (Priyanto, 2009).

3. Media hasil gabungan tenologi cetak dan teknologi computer

Teknologi gabungan adalah cara untuk menghasilkan dan menyampaikan materi yang menggabungkan pemakaian beberapa bentuk media yang dikendalikan komputer. Komputer yang memiliki kemampuan yang hebat seperti jumlah random memori yang besar, hard disk yang besar, dan monitor yang beresolusi tinggi ditambah dengan pararel (alat-alat tambahan), seperti video disk player, perangkat keras untuk bergabung dalam suatu jaringan dan sistem audio.

\section{Pemanfaatan Media Pembelajaran Sebagai Sumber Belajar Dalam Bidang Bimbingan Konseling}

1. Media Berbasis Visual

Keberhasilan penggunaan media berbasis visual ditentukan oleh kualitas dan efektifitas bahan-bahan visual dan grafik itu. Hal ini dapat dicapai dengan mengatur dan mengorganiasikan gagasan-gagasan yang timbul, merencanakannya dengan seksama, dan menggunakan teknik teknik dasar evaluasi objek, konsep, informasi, atau situasi.

Jika mengamati bahan-bahan grafis, gambar, dan lain-lain yang ada di sekitar kita, kita akan menemukan gagasan untuk merancang bahan visual yang menyangkut penataan elemen elemen visual yang akan ditampilkan. Dalam proses penataan itu harus diperhatikan prinsip-prinsip, antara lain prinsip kesederhanaan, keterpaduan, penekanan, dan keseimbangan.

a. Kesederhanaan. Kesederhanaan itu mengacu pada jumlah elemen yang terkandung dalam suatu visual. Jumlah elemen yang lebih sedikit memudahkan siswa menangkap dan memahami pesan yang disajikan visual itu.

b. Keterpaduan. Keterpaduan mengacu pada hubungan yang terdapat diantara elemen-elemen visual yang ketika diamati akan berfungsi secara bersam-sama.

c. Penekanan. Meskipun penyajian visual dirancang sesederhana mungkin, seringkali konsep yang ingin disajikan memerlukan penekanan terhadap salah satu unsur yang akan menjadi pusat perhatian siswa.

d. Keseimbangan. Bentuk atau pola yang dipilih sebaiknya menempati ruang penayangan yang memberikan persepsi keseimbangan meskipun tidak seluruhnya simetris. Keseimbangan yang keseluruhannya simetris disebut 
keseimbangan formal. (Kawuryan \& Raharjo, 2012).

\section{Media Berbasis Audio Visual}

Media audio dan audio visual merupakan bentuk media pembelajaran yang murah dan terjangkau. Audio dapat menampilkan pesan yang memotivasi siswa. Berikut jenis-jenis media berbasis audio visual. Penggunaan media audio sangat mendukung sistem pembelajaran tuntas. Meskipun tidak ada prosedur baku tentang penggunaan bahan-bahan audio, sebaiknya materi audio itu disajikan dengan mengikuti langkah-langkah sebagai berikut:

a. Mempersiapkan diri. Yaitu guru harus menyiapkan diri sebelum penyajian materi. Salah satu cara mempersiapan diri adalah dengan memeriksa dan mencobakan materi itu.

b. Membangkitkan kesiapan siswa. Siswa dituntun agar memiliki kesiapan untuk mendengar, misalnya dengan memberikan komentar awal dan pertanyaanpertanyaan.

c. Mendengarkan materi audio. Guru harus menuntun siswa untuk menjalani pengalaman mendengar dengan waktu yang tepat atau dengan sedikit penundaan antara pengantar dan mulainya proses mendengar.

d. Diskusi (pembahasan) materi program audio. Sebaiknya setelah selesai mendengar program itu, diskusi dimulai dengan mengajukan pertanyaanpertanyaan. e. Menindaklanjuti program. Guru harus memotivasi siwa untuk mempelajari lebih banyak tentang pelajaran itu.

3. Kombinasi Slide dan Suara

Gabungan Slide (film bingkai) dengan tape audio adalah jenis sistem multimedia yang paling mudah diproduksi. Media pembelajaran gabungan slide dan tape dapat digunakan pada berbagai lokasi dan untuk berbagai tujuan pembelajaran yang melibatkan gambar-gambar guna menginformasikan atau mendorong lahirnya respons emosional.

Keefektifan penyajian pelajaran melalui multimedia seperti ini memerlukan perhatian khusus kepada faktor-faktor sebagai berikut:

a. Sajikan konsep-konsep satu per Satu

b. Gunakan bidang penayangan dilayar untuk tujuan-tujuan tertentu untuk menyampaikan pesan materi pelajaran.

c. Susunlah unsur-unsur gambar itu dan aturlah hubungan atara unsurunsur itu, dengan pertimbangan bahwa pesan utama diletakan ditengah tengah layar dan informasi lainnya pada sisisisinya.

d. Pilihlah slide yang berkualitas.

e. Pilihlah musik yang dapat menyentuh perasaan untuk penyajian, tetapi perhatikan jangan sampai musik mengatasi narasi.

f. Gunakan efek suara asli untuk memberikan bayangan realism dalam penyajian. 
g. Jangan terlalu banyak narasi.

h. Dalam beberapa hal, penggunaan lebih dari satu suara dalam narasi akan membuat penyajian lebih dinamis. (Atmaja, 2019).

\section{Media Berbasis Komputer}

Disamping digunakan untuk keperluan administrasi dan pengembangan usaha pada perusahaan besar dan kecil, komputer pun mendapat tempat di sekolahsekolah. Misalnya untuk mencari berapa jumlah kata dalam Al-Quran dan pada surat dan ayat berapa serta apa bunyi ayatnya tidak perlu lagi membuka fathurrohman atau almu'jam al-mufahras Berikut pemanfaatan media berbasis komputer :

a. Tutorial. Program pembelajaran tutorial dengan bantuan komputer meniru sistem tutor yang dilakukan oleh guru atau instruktur. Informasi atau pesan berupa suatu konsep disajikan dilayar computer dengan teks, gambar, atau grafik.

b. Drills and Practice (Latihan). Latihan untuk mempermahir keterampilan atau memperkuat penguasaan konsep dapat dilakukan dengan modus drills and practice. Komputer

c. menyiapkan serangkaian soal atau pertanyaan yang serupa dengan yang biasa ditemukan dalam buku/lembarn kerja work book.

d. Simulasi. Program simulasi dengan bantuan komputer mencoba untuk menyamai proses dinamis yang terjadi di dunia nyata. e. Permainan Instruksional. Program permainan yang dirancang dengan baik dapat memotivasi siswa dan meningkatkan pengetahuan dan keterampilannya. Permainan instruksional yang berhasil menggabungkan aksi-aksi permainan video dan keterampilan penggunaan papan ketik pada komputer.

5. Multimedia Berbasis Komputer dan Interaktif video

Multimedia secara sederhana ia di artikan sebagai lebih dari satu media. Ia bisa berupa grafik, animasi, suara, dan video. Pada bagian ini perpaduan dan kombinasi dua atau lebih jenis media ditekankan kepada kendali komputer sebagai penggerak keseluruhan gabungan media itu. Dengan demikian, arti multimedia yang umumnya dikenal dewasa ini adalah berbagai macam kombinasi grafik, teks, suara, video, dan animasi. Penggabungan ini merupakan satu kesatuan yang secara bersama-sama menampilkan informasi, pesan atau isi pelajaran.

6. Media Berbasis Internet

Internet juga dapat digunakan sebagai sumber alternatif selain buku untuk memudahkan mencari informasi sebanyak mungkin, internet adalah sebagai sumber belajar yang dimanfaatkan oleh guru dalam mengembangkan profesinya, karena dengan internet guru dapat meningkatakan pengetahuan, berbagi informasi diantar rekan sejawat, bekerjasama dengan pengajar di luar negri, kesempatan mampublikasikan informasi secara langsung, dan mengatur kominikasi secara teratur. Pemanfaatan 
internet sebagai sumber pembelajaran mengkondisikan peserta didik untuk belajar secara mandiri. Siswa dapat mengakses secara online sumber belajar seperti mencari informasi pembelajaran melalui google dan yahoo, mencari data yang berkaitan dengan pelajaran dan perpustakaan online (Hamka, 2015).

Pemanfaatan jaringan internet sebagai sumber dan sarana pembelajaran, dapat di implementasikan sebagai berikut:

a. Browsing, merupakan istilah umum yang digunakan bila hendak menjelajahi dunia maya/web.

b. Ressourcing adalah menjaikan internet sebagai sumber pengajaran.

c. Searching merupakan proses pencarian sumber pembelajaran guna melengkapi materi yang akan disampaikan kepada peserta didik.

\section{d. Consulting dan Communicating} Dengan adanya internet guru dan siswa menjadi sanggat terbantu ketika mencari informasi yang berhubungan dengan pembelajaran karena menurut Association for Educational Communications and Technology sumber belajar adalah segala sesuatu atau daya yang dapat dimanfaatkan oleh guru, baik secara terpisah maupun dalam bentuk gabungan, untuk kepentingan belajar mengajar, dengan tujuan meningkatkan efektifitas dan efisiensi tujuan pembelajaran. Sumber pembelajaran dapat kelompokkan menjadi dua bagian yaitu:

a. Sumber pembelajaran yang sengaja direncanakan (learning resources by design), yakni semua sumber yang secara khusus telah dikembangkan sebagai komponen sistem intruksional untuk memberikan fasilitas belajar yang terarah dan bersifat formal; dan

b. Sumber belajar yang karena dimanfaatkan (learning resources by utilization), yakni sumber belajar yang tidak secara khusus di desain untuk keperluan pembelajaran namun dapat ditemukan, diaplikasikan dan dimanfaatkan untuk keperluan belajar salah satunya adalah media masa. (Mahnun, 2012)

Internet adalah sebuah media belajar yang dapat dimanfaatkan sebagai sumber belajar dalam aktivitas belajar, sehingga siswa dapat memperoleh informasi atau bahan belajar dengan cepat. Internet dengan berbagai fasilitas-fasilitas yang dimiliki dapat menjadi komponen penting dalam kegiatan belajar, khususnya sebagai sumber belajar. Berbagai informasi yang dapat digali melalui internet, sehingga dapat mempermudah proses belajar. Hal tersebut sejalan dengan pendapat Setiyani yang mengatakan bahwa internet memiliki banyak manfaat bagi akademisi, khususnya mahasiswa karena internet dan memudahan dalam pencarian jurnal, referensi, materi kuliah, hingga hasil penelitian yang dipublikasikan dalam jumlah yang banyak dan cepat, sehingga dapat menghemat tenaga 
dan biaya dalam mencari sumber belajarnya. manfaat internet bagi pendidikan, antara lain untuk akses ke sumber informasi, akses ke pakar, maupun media kerjasama.

Selain itu, media yang bisa dimanfaatkan sebagai sumber belajar pada layanan bimbingan konseling adalah: (Prasetiawan \& Alhadi, 2018).

1. Pemanfaatan Media pada Layanan Orientasi

2. Pemanfaatan Media pada Layanan Informasi

3. Pemanfaatan Media pada Layanan Konseling Perorangan

4. Pemanfaatan Media pada Layanan Konseling Kelompok

5. Pemanfaatan Media pada Layanan Bimbingan Kelompok

6. Pemanfaatan Media pada Layanan Penguasaan Konten

\section{SIMPULAN}

Berdasarkan kajian diatas maka sumber belajar dapat diartikan sebagai bahan baku utama ketika hendak melakukan proses pembelajaran, dalam hal ini termasuk pemberian pelayanan bimbingan dan konseling. Saat ini, Bimbingan dan konseling yang merupakan bagian utuh dalam sistem pembelajaran maka dapat memanfaatkan beragam sumber belajar yang tersedia. Terdapat media digital berupa video dan audio, teknik pendekatan agar tercipta suasana nyaman dengan siswa atau klien dan tempat pemberian layanan yang di khususkan agar proses pemberian layanan bimbingan dan konseling berjalan dengan baik, sistematis, dan terukur.

\section{DAFTAR PUSTAKA}

Abdullah, R. (2012). Pembelajaran Berbasis Pemanfaatan Sumber Belajar. Jurnal Ilmiah Didaktika: Media Ilmiah Pendidikan dan Pengajaran, 12(2), 3045.

Arifin, L. (2013). Upaya Konselor dalam Membimbing Belajar Siswa di Sekolah Dasar/Madrasah Ibtidaiyah. Jurnal Bimbingan Konseling Islam, 4(2), 201218.

Atmaja, H. T. (2019). Pelatihan dan Pendampingan Pembuatan dan Pemanfaatan Media Audio-Visual Interaktif dalam Pembelajaran Sejarah Yang Berbasis pada Konservasi Kearifan Lokal Bagi MGMP sejarah Kabupaten Banjarnegara. Jurnal Panjar: Pengabdian Bidang Pembelajaran, 1(2), 131-140.

Basri, A. S. H. (2010). Peran media dalam Layanan Bimbingan Konseling Islam di Sekolah. Jurnal Dakwah, 11(1), 23-41.

Basri, A. S. H. (2018). Urgensi Penggunaan Teknologi Media dalam Implementasi Bimbingan dan Konseling di Sekolah. Al-Isyraq: Jurnal Bimbingan, Penyuluhan, dan Konseling Islam, 1(1), 83-107.

El Fiah, R., \& Purbaya, A. P. (2016). Penerapan Bimbingan Belajar dalam Meningkatkan Hasil Belajar Peserta Didik di SMP Negeri 12 Kota Bandar Lampung Tahun Pelajaran 2015/2016. Konseli: Jurnal Bimbingan Dan Konseling (E-Journal), 3(2), 171-184.

Hamka, H. (2015). Penggunaan Internet Sebagai Media Pembelajaran Pada Mahasiswa IAIN Palu. Hunafa: Jurnal Studia Islamika, 12(1), 95-119.

Kawuryan, F., \& Raharjo, T. (2012). Pengaruh Stimulasi Visual untuk Meningkatkan Kemampuan Membaca pada Anak Disleksia. Jurnal Psikologi: Pitutur, 1(1), 9-18.

Mahnun, N. (2012). Media Pembelajaran 
(Kajian Terhadap Langkah-Langkah Pemilihan Media dan Implementasinya dalam Pembelajaran). An-Nida', 37(1), 27-34.

Prasetiawan, H. (2017). Optimalisasi Multimedia Dalam Layanan Bimbingan dan Konseling. Prosiding Seminar Bimbingan dan Konseling, 1(1), 199204.

Prasetiawan, H., \& Alhadi, S. (2018). Pemanfaatan Media Bimbingan dan Konseling di Sekolah Menengah Kejuruan Muhammadiyah se-Kota Yogyakarta. Jurnal Kajian Bimbingan dan Konseling, 3(2), 87-98.

Priyanto, D. (2009). Pengembangan multimedia pembelajaran berbasis komputer. Insania: Jurnal Pemikiran Alternatif Kependidikan, 14(1), 92-110.

Seels, B. B., \& Richey, R. C. (2012). Instructional technology: The definition and domains of the field. IAP.

Setiawan, M. A. (2018). PendekatanPendekatan Konseling (Teori Dan Aplikasi). Deepublish.

Sodik, A. (2016). Konseling Sebagai Suatu Sistem Pendidikan Sekolah. Hisbah: Jurnal Bimbingan Konseling Dan Dakwah Islam, 13(1), 1-17.

Tafonao, T. (2018). Peranan Media Pembelajaran dalam Meningkatkan Minat Belajar Mahasiswa. Jurnal Komunikasi Pendidikan, 2(2), 103-114.

Warsita, B. (2018). Teori Belajar Robert M. Gagne dan Implikasinya pada Pentingnya Pusat Sumber Belajar. Jurnal Teknodik, 12(1), 64-78.

Yuhana, A. N., \& Aminy, F. A. (2019). Optimalisasi Peran Guru Pendidikan Agama Islam Sebagai Konselor Dalam Mengatasi Masalah Belajar Siswa. Jurnal Penelitian Pendidikan Islam, 7(1), 79-96. 